\title{
Des "choix techniques" en question : le discours de l'architecture "régionaliste"
}

Richard Klein

\section{(2) OpenEdition \\ 12 Journals}

Édition électronique

URL : https://journals.openedition.org/tc/942

DOI : $10.4000 /$ tc. 942

ISSN : 1952-420X

Éditeur

Éditions de l'EHESS

\section{Édition imprimée}

Date de publication : 1 février 1986

ISSN : 0248-6016

\section{Référence électronique}

Richard Klein, "Des "choix techniques" en question : le discours de l'architecture "régionaliste" », Techniques \& Culture [En ligne], 6 | 1986, mis en ligne le 24 janvier 2006, consulté le 29 septembre 2022. URL : http://journals.openedition.org/tc/942 ; DOI : https://doi.org/10.4000/tc.942

Ce document a été généré automatiquement le 29 septembre 2022.

Tous droits réservés 
Des "choix techniques" en question : le discours de l'architecture "régionaliste"

Richard Klein 